Australian Journal of Basic and Applied Sciences

\title{
Mode of Islamic Bank Financing: Does Effectiveness of Shari'ah Supervisory Board Matter?
}

${ }^{1}$ Waeibrorheem Waemustafa. PhD. and ${ }^{2}$ Azrul Abdullah

${ }^{I}$ School of Economics, Finance and Banking, College of Business (COB), Universiti Utara Malaysia 06010 Sintok, Kedah, Malaysia

${ }^{2}$ Faculty of Accountancy Universiti Teknologi MARA (Perlis), 02600 Arau, Perlis, Malaysia

\begin{tabular}{l}
\hline A R T I C L E I N F O \\
\hline Article history: \\
Received 10 October 2015 \\
Accepted 30 November 2015 \\
Available online 31 December 2015 \\
Keywords: \\
Shari'ah Supervisory Board, Mode of \\
Financing, Islamic Bank.
\end{tabular}

Financing, Islamic Bank.

\begin{abstract}
A B S T R A C T
This paper examines the relationships between the effectiveness of Shari'ah supervisory board (SSB), their remuneration and mode of financing of Islamicbank. The SSB effectiveness is evaluated by an index based on 9 attributes score. This study comprises 18 Islamic banks in which operating in Malaysia from the year 2012 to 2014 as a sample. Our regression analysis shows that the effectiveness of SSB does not concern with the mode of Islamic bank financing. However, we found that SSB remuneration and bank's financial growth shown a positive and significant relationship with mode of financing. The implications of these findings are discussed.
\end{abstract}

(C) 2015 AENSI Publisher All rights reserved

ToCite ThisArticle:W., Waemustafa and A., Abdullah, Mode of Islamic Bank Financing: Does Effectiveness ofShari'ah Supervisory Board Matter?.Aust. J. Basic \& Appl. Sci., 9(37): 458-463, 2015

\section{INTRODUCTION}

There is a strong debut on the Islamic mode of financing which do not underlie with the banner of Islamic banking in which constitutes the elimination of injustices of the interest-based system as ordained by Holy Qur'an. According to Rosly, et al., (2011), Anwar, et al., (2003) and Usmani, (2004) the current mode of financing still cannot be expected to completely free from the injustices of the interestbased system or to contribute to the achievement of socioeconomic objectives which Islam seeks to achieve. Although there are many views can be discussed towards the mode of financing adopted by the Islamic banks, this study aims to explain whether Shari'ahsupervisory boards (SSB) and their remuneration have any significant influence towards the choices of Islamic banks mode of financing. Based on the work of Ahmad, (2014) who suggested that, SSB plays an important role, particularly in harmonizing the Islamic rules and guidelines in Islamic banks (i.e.,Shari'ah-compliance gatekeeper), this study argued that the choices of style of financing by Islamic banks should be tempted by this board as to avoid any injustices as what has been proposed in Shari'ah Law. In other words, the SSB should put highly concern with regard to any mode of financing by the Islamic bank in which are not aligned with the profit- sharing principles.

\section{Literature Review:}

Islamic mode of financing drawbacks:
According to Rosly, (2010) there are five drawbacks of Murabahah or mark-up based mode of financing. First, on the matter of ownership and ownership whereby bank has been claimed not actually purchase the asset prior to sale. Second, is on the issue of Murabahah's pricing mechanism. Third, is on the extent profit determination with consideration of time value of money with a fixed compensation since the Murabahah deals with installment sale. Fourth, the issue of customer defaulted toward Murabahah facility. Fifth, refer to the liability of an asset that found defective upon delivery and lastly is on the principle of al-kharaj bil daman where entitlement for gain subjects to liability for loss that being applied in the contract.

\section{Shari'ah Governance:}

According to Alman, (2012), Shari'ah Supervisory Board (SSB) is one of internal governance mechanisms which involves the monitoring of Islamic banks' activities in accordance to the Sharia (i.e. Islamic law) specifically on its implementation and compliance. It is a part of the big corporate governance framework and what makes it different is only by the existence of Shari'ah Supervisory Board or Shari'ah Supervisory Committee or Shari'ah unit (Rahajeng, 2012). Since Shari'ah governance is part of corporate governance, thus, good and effective SSB should reflect the issue of independence, transparent, accountable, responsible, and fair Bhatti and Bhatti (2010). In this context, studies by Grais and Pellegrini (2006) and 
Farook, and Lanis (2011), argued that the unique attributes of SSB must be clarified as to incorporating SSB as part of corporate governance mechanisms framework. Although the existence of SSB seemed to be able to monitor Islamic banking activities, there are still Islamic banks have experienced failure similar to that of conventional in the recent year. Supposedly, by the attaining of Shari'ah and good corporate governance, Islamic bank basically able to achieve Shari'ah objectives (i.e., Maqasid Shari'ah). However, having this kind of committee is sort not like providing reliable Shari'ah Governance in which utmost important and beneficial to all parties inside and outside the Islamic Banks.

\section{Issues on Shari'ah Supervisory Board:}

It is prevalent that the roles of shari'ah supervisory council, shari'ah committee or shari'ah supervisory board emphasized on matter pertaining to shari'ah compliance see (Besar, et al., 2009). These committees do not participate directly in the risk management process as evidenced from the Islamic banks annual reports shows that SSB does not appear in the risk management committee. The opinion of the SSB of shari'ah related matters are reported to the board of directors as they are the one who make the final decision.

Hence, the shari'ah committee basically exists merely to fulfill the central bank of Malaysia or BNM's requirement for Islamic banks establishment. The interest of board of directors may depart from interest of their stakeholders in the context of Ummah or Muslim nation and community. Thus, it is very important to understand that to whom these SSB are accountable and how far it existence is really relevant at the banks level.

A study by Hasan, (2011) shows that SSB is accountable to the board of directors in many respects as their remuneration, appointment and dismissal are subjected to the approval of the board of directors at bank level. The existences of superior board at central banks level also known as shari'ah advisory council should be sufficient to guide Islamic bank to comply with shari'ah requirements.

The rationale of having two-tier board system was aimed to provide better supervisory at a higher agency cost from shareholders or depositors return. The existence of SSB should have contributed greatly for the betterment of the ummah through promoting profit and loss sharing based financing. On contrary, the SSB committee at bank level was established to minimize reputational risk originated from shari'ah noncompliance matters see (Akhtar, 2006). However, the Islamic banks' reputational risk may arises from other sources such as risk taking appetite of Islamic banks' financing portfolio which is predominately of debt based such as Murabahah and Baibhithaman Ajil. From the preliminary analysis of the annual report shows that more than
$50 \%$ of Islamic bank portfolio is concentrated in nonprofit and loss sharing mode.

\section{Profitability:}

Net profit after taxes to total assets was used as proxy for determining banks profitability. Ahmad and Mohammad (2011) shows that ROA is negatively significant to credit risk, which implies that increase in credit risk reduce Islamic banks profitability in Middle East and Southeast Asia countries. Cebenoyan and Strahan (2004) show banks that engage in buying and selling loans to manage credit risk increase their profitability.

Ahmad and Mohammad (2010) show that technical and scale efficiency is positively significant to credit risk. The increases of return on assets and profitability reduce credit risks for conventional banks, according to Miller and Noulas (1997) and Said and Tumin (2011) show that as banks were exposed to high-risks loans, their higher accumulation of unpaid loans result in lower profitability.

Boudriga, et al.(2009) explain that association between performance and risk does not hold at aggregate level rather it may hold at bank level. The possible explanations for this phenomenon could be due to both are operating side by side in the same economic environment, which possibly exposed them to similar risk. Another possible reason is that interest rate was used as benchmark by Islamic banks to determine profit rate as a result they are rivaling against each other to generate profit from the same market Nienhaus (1983).

The past research of Bader et al. (2008), Mohamad et al. (2008) who found that there are no difference in term of profit between Islamic banks and conventional banks in GCC, MENA, ASIA and South East Asia. Hence, the sources of credit risk is created with excessive concentration of financing in risky sectors which is prominent for Murabahah and Bai Bhithaman ajil financing that is mainly in construction, property and real estate sectors which is prone to higher risk.

\section{Macroeconomic factor: Money Supply:}

Broad money (M3) indicates that increase in money supply lower the credit risk as the borrowers able to service their loan obligations as suggested in Ahmad and Ariff (2007) suggest that increase in money supply reduce the interest rate as borrower were able to obtain cheaper fun consequently reduce credit risk whereas lower money supply increase credit risks. According to Haron and Wan Azmi (2008) Kok et al. (2012) indicates that positive significant to banks profit which implies that Islamic banks were able to generate more profit when central bank's eases up the money supply policy conversely this would have negative significant to credit risk as reported in previous studies (Bourke, 1989), 
(Molyneux and Thornton, 1992), (Haron and Azmi, 2004) and (Haron, 1996).

GDP:

GDP was used as indicators for overall economic activities. Haq and Heaney (2012) suggest that improve in economic performance as indicate by GDP growth reduce credit risk. Marcucci and Quagliariello (2009) the study shows that during economic downturn risky portfolio bank exposed to credit risks compared less risky ones. Jakubík (2007) higher GDP growth leads to lower credit risk which is consistent to intuition of economic theory as also found in Jakubík (2007) and Castro (2013) suggest that deterioration of economic growth leading to unemployment consequently increases in credit risk. According toBoudrigaet al.(2009) suggest that economic health contribute to explain problem loan, economic recovery improve borrower credit quality in facilitatingof repayment especially in developing economies

\section{Hypotheses Development:}

This study employs agency theory as underpinning theory to develop the hypotheses. The following hypotheses have been developed in this study:

$\mathbf{H}_{1}$ There is positive relationships between the effectiveness of SSB and mode offinancing adopted by the Islamic bank.

$\mathbf{H}_{2}$ There is no significant relationship between SSB remuneration and mode of financing adopted by the Islamic bank.

Methodology:
Sample of this study comprises 18 Islamic banks in which operating in Malaysia from the year 2012 till 2014. To extract the mode of financing and information about SSB (i.e., effectiveness and remuneration), the annual reports of Islamic bank were scrutinized.

The dependent variable of this study denoted as MODE is proxy by Bai Bhithaman Ajil (deferred payment sales)to total Finance. This study measured SSB effectiveness based on 9 attributes scored in which aggregately measured. The attributes is captured based on four elements of effectiveness which is proposed in conventional corporate governance model (Ika and Ghazali, 2012; DeZoort, et al., 2002). These elements are 1) composition, 2) adequate authority, 3) resources and 4) diligence. Since Shari'ah governance is part of corporate governance model (Farook et al., 2011), the use of this elements can be assumed valid.

The study employs ordinary least square OLS on the dependent variables denoted as MODE and six independent variables namely SSBREMU, FGROWTH, PROF, MSUPP, GDP and SSBEFF or the efficiency index of shari'ah supervisory board which is measured based on thier nationality, qualification, gender diversity, shari'ah compliance oriented, risk management partcipation, size of SSB board, number of meeting and experience.

The score is given based on the disclosed items. Each disclosed score is assigned with 1 for disclose where 0 undiscosed. Hence, the accumulated score is total up to determine the index score. Those banks with highest disclosure produce higher index score. FGROWTH is proxy for financing growth based on total financing of Islamic banks.

Table 1: Measurement of Explanatory Variables

\begin{tabular}{lll}
\hline Variable & & Composition of variables \\
\hline MODE & $:$ & $\begin{array}{l}\text { Bai Bhithaman Ajil to Total Finance } \\
\text { SSBEFF }\end{array}$ \\
& $:$ & $\begin{array}{l}\text { SSB effectiveness Index = Company's actual score on SSB characteristics/ company } \\
\text { total possible score of SSB characteristics }\end{array}$ \\
SSBREMU & $:$ & Log of Total Remuneration \\
FGROWTH & $:$ & Log of Total Finance \\
PROF & $:$ & Net profit to Total assets \\
MSUPP & $:$ & M2 plus financial assets \\
GDP & $:$ & Growth rate of real GDP \\
$\varepsilon$ & $:$ & Error term \\
\hline
\end{tabular}

To examine the relationship between SSB effectiveness, remuneration, control variables and the mode of financing, a multiple linear regression is performed. The regression model is built as follows:

\footnotetext{
$\mathrm{MODE}_{i}=$ $\alpha_{\mathrm{i}}+\boldsymbol{\beta} 1$ SSBEFF $_{\mathrm{i}}+\boldsymbol{\beta} 2$ SSBREMU $_{\mathrm{i}}+\boldsymbol{\beta} 3 \mathrm{FGROW}$ $\mathrm{TH}_{\mathrm{i}}$$$
+\boldsymbol{\beta} 4 \mathrm{PROF}_{\mathrm{i}}+\boldsymbol{\beta} 5 \mathrm{MSUPP}_{\mathrm{i}}+\boldsymbol{\beta 6 G D P}_{\mathrm{i}}+\varepsilon_{\mathrm{i}}
$$

\section{RESULTS AND DISCUSSION}

Descriptive statistics for the variables is shown in Table 2. The average of MODE is 53 percent indicating that more than half of the total finance is dominated by Bai bhithaman Ajil. The mean score of 0.7857 for SSBEFF indicates that on average, SSB in Malaysia quite effective. On average, all the SSB members are being paid of RM518, 346 annually, however, there are some bank that did not disclose the SSB remuneration clearly.

The study shows that the assets size of Islamic banks are consist of small, medium and large banks where high standard deviation of .78972 indicates that banks are differences in size with average size of 
RM27,942,718.

The financing growth on the other hand shows that on average the banks growth at 3.8\% during the study period with high standard deviation 1.25395. This could be the result of different financing strategy adopted by each bank their financing portfolio are different in its compositions subject to their risk preferences. The PROF ratio exhibits that on average the Islamic banks earn $8.6 \%$ profit during the period of study with standard deviation of 0.02689this implies that Islamic banks profit are at the same level regardless of their differences in size.

Table 2: Descriptive Results

\begin{tabular}{|l|l|l|}
\hline $\mathrm{N}=42$ & Mean & Standard Deviation \\
\hline & .5295 & .23113 \\
\hline MODE & .7857 & .06639 \\
\hline SSBEFF & 12.7312 & .78972 \\
\hline SSBREMU & 16.1884 & 1.25395 \\
\hline FGROWTH & .0864 & .02689 \\
\hline PROF & 2.300 & .5959 \\
\hline MSUPP & 8.300 & 1.0054 \\
\hline GDP & & \\
\hline
\end{tabular}

Table 3 presents the outcomes of the regression analysis between the Mode of financing, SSB effectiveness and control variables. The Variance Inflation Factor (VIF) statistics indicate that multicollinearity does not exist in the model as the values are less than 10 . The model explains 22.3 percent of the variation towards the mode of financing, which is relatively low. Although the adjusted $R^{2}$ is low, the finding is consistent with those of the previous governance studies, which pointed out that the low $\mathrm{R}^{2}$ iscommon in corporate governance researches see (Farook, et al., 2011)and(Abdul Rahman, et al., 2013). Our analysis show that SSBEFF does not have significant relationship with mode of financing but there are significant relationship between SSBREMU and FGROWTH. Table 3 shows that SSBREMU (t value $=1.77$ ) has a significant and positive relationship with the mode of Islamic bank financing, at $\mathrm{p}<0.1$ in which indicates that the increase in BBA moves in tandem with the increase in SSB's remuneration.

It's not a matter of SSB effectiveness, but it seems that their remuneration may determine the preferences toward BBA and Murabahah mode of financing. This might hold a truth since we found that there is an insignificant portion of these asset portfolios is mainly dominated by murabahah, BBA and other than profit and loss mode of financing. In addition, judging from the FGROWTH that is positively significant to MODE as reported, we also perceived that the trade-based mode of financing that must be applied temporarily by Islamic bank as for their transitional phase is not much concern after 25 years, it sort like they are maximizing the shareholders wealth.

Table 3: Regression Results

\begin{tabular}{|c|c|c|c|c|c|c|}
\hline Model & Pred. Sign & Coeff. & SE & $\mathrm{t}$ & Sig. & VIF \\
\hline (Constant) & & -1.454 & 1.077 & -1.35 & .186 & - \\
\hline SSBEFF & + & -.017 & 0.574 & -.029 & .977 & 1.322 \\
\hline SSBREMU & 0 & .086 & .049 & 1.77 & $.085^{*}$ & 1.338 \\
\hline \multicolumn{7}{|c|}{ Control Variables } \\
\hline FGROWTH & + & .067 & .038 & 1.77 & $.085^{*}$ & 2.032 \\
\hline PROF & + & .724 & 1.614 & .448 & .657 & 1.716 \\
\hline MSUPP & $+/-$ & -.058 & .089 & -.648 & .521 & 2.574 \\
\hline GDP & $+/-$ & -.013 & .055 & -.245 & .808 & 2.774 \\
\hline$\overline{\mathrm{R}^{2}}$ & 0.228 & $P$ value & 0.059 & & & \\
\hline Adjusted $\mathrm{R}^{2}$ & 0.203 & $\mathrm{~N}$ & 42 & & & \\
\hline F statistic & 2.275 & & & & & \\
\hline
\end{tabular}

In another view, the ineffectiveness of SSB committee can be excused due to a relationship with the management making way for their long period of trust (see Ika and Ghazali, 2012; Rahman et al. 2012). SSB assessment may have been influenced by the management decisions since their appointment to the board is merely due to their relationship with the company. The study includes gross domestic product GDP and money supply MSUPP as external determinants.However, the finding shows negative but insignificant of both macroeconomic factors on the financing preference of Islamic banks with p- value $=0.521$ and 0.808 respectively. This is consistant with the notion that Islamic banks are crisis proof given the unique assets and liabilities that allow Islamic banks to share their risk with its investment account holders. This internal liquidity advantage allows Islamic banks to absorb the shocks in the event of financial turmoil.

\section{Conclusion:}

The objective of this study is to examine the influence of SSB effectiveness and their remuneration to the choices of Islamic mode of 
financing by Malaysian Islamic bank. The analysis shows that an effective SSB does not have significant bearing towards the choice of Islamic mode of financing in Malaysia but their remuneration have. Intrinsically, this finding might give some insight towards the notion of 'cosmetic reason' (Zaman, et al., 2001) for regulator, policy maker and another researcher on the effectiveness and the existence of SSB in Malaysia especially when incorporating SSBs as part of the corporate governance mechanism. However, it should be noted that the finding in this study is considered small due to the some limitation and should becarefully generalized by other researcher. It is suggested that further studyto be conducted by extending more observation

\section{REFERENCES}

Abdul Rahman, A. and B.A. Awadh, 2013. The influence of the Shari'ah supervision board on corporate social responsibility disclosure by Islamic banks of gulf co-operation council countries, Asian Journal of Business and Accounting, 6: 65-104.

Ahmad, N.H. and A. Ariff, 2007. Multi-country study of bank credit risk determinants. The Journal of banking and Finance, 5(1): 135-152

Ahmad, N.H.B. and M.A.N.B. Mohamad, 2010. "The Determinants Efficiency and Profitability of World Islamic Banks." International Conference on E-Business, Management and Economics, IPEDR 3.

Ahmad, N.H.B. and M.A.N.B. Mohamad, 2011. "The Impact of 1998 and 2008 Financial Crisis on Profitability of Islamic Banks." Bangladesh Development Studies, XXXIV 34(1): 1.

Ahmed, H., 2014. Islamic Banking and Shari'ah Compliance: A Product Development Perspective. Journal of Islamic Finance, 3: 15-29.

Akhtar, S., 2006. Syariah Compliant Corporate Governance. In Keynote address by the governor of the State Bank of Pakistan at the annual Corporate Governance Conference, Dubai, United Arab Emirates.

Alman, M., 2012. Shari'ah supervisory board composition effects on Islamic banks' risk-taking behavior.Journal of Banking Regulation, 14: 134163.

Anwar, M., 2003. Islamicity of banking and modes of Islamic banking.Arab Law Quarterly, pp: 62-80.

Bader, M.K.I., S. Mohamad, M. Ariff and T. Hassan, 2008. Cost, revenue and profit efficiency of Islamic versus conventional banks: international evidence using data envelopment analysis. Islamic Economic Studies, 15(2): 23-76.

Besar, M.H.A., Mohd Edil Abd Sukor, Nuraishah Abdul Muthalib and Y.G. Alwin, 2009. The practice of Shari'ah review as undertaken by Islamic banking sector in Malaysia.International Review of Business Research Papers, 5(1): 294-306.
Bhatti, M. and M.I. Bhatti, 2010.Toward understanding Islamic corporate governance issues in Islamic finance.Asian Politics and Policy, 2: 25-38.

Boudriga, A., N. Boulila Taktak and S. Jellouli, 2009. Banking supervision and nonperforming loans: a cross-country analysis. Journal of financial economic policy, 1(4): 286-318.

Bougdriga, A., N.B. Taktak and S. Jellouli, 2009. "Banking Supervision and nonperforming loans: a cross-country analysis". Journal of Financial Economic Policy, 1(4): 286-318.

Bourke, P., 1989. Concentration and other determinants of bank profitability in Europe, North America and Australia. Journal of Banking \& Finance, 13(1): 65-79.

DeZoort, T., D. Hermanson, D. Archambeault and S. Reed, 2002. Audit committee effectiveness: a synthesis of the empirical audit committee literature, Journal of Accounting Literature, 21: 38-75.

Farook, S., K. Hassan and R. Lanis, 2011. Determinants of corporate social responsibility disclosure: The case of Islamic banks. Islamic Accounting and Business Research, 2: 114-141.

Grais, W. and M. Pellegrini, 2006. Corporate governance in institutions offering Islamic financial services: issues and options, World Bank Policy Research Working, pp: 4052.

Haq, M. and R. Heaney, 2012.Factors determining European bank risk. Journal of International Financial Markets, Institutions and Money, 22(4): 696-718.

Haron, S., Wan Azmi, Wan Nursofiza., 2008. Determinants of Islamic and conventional deposits in the Malaysian banking system. Journal of Management Finance, 31(9): 618-643.

Hasan, Zulkifli, 2011. A survey on Shari'ah governance practices in Malaysia, GCC countries and the UK: Critical appraisal. International Journal of Islamic and Middle Eastern Finance and Management., 4(1): 30-51.

Ika, S.R., and N.A.M. Ghazali, 2012. Audit committee effectiveness and timeliness of reporting: Indonesian evidence, Managerial Auditing Journal, 27: 403-424.

Jakubík, P., 2007. Macroeconomic environment and credit risk. Czech Journal of Economics and Finance (Finance a uver), 57(1-2): 60-78.

Kok, Y.T., S.Y. Tan, M.S. Yong and K.W. Tan, 2012. The determinants of Islamic banks profitability in Malaysia (Doctoral dissertation, UTAR).

Marcucci, J. and M. Quagliariello, 2009. Asymmetric effects of the business cycle on bank credit risk. Journal of Banking \& Finance, 33(9): 1624-1635.

Miller, S.M. and A.G. Noulas, 1997. Portfolio mix and large-bank profitability in the USA.Applied Economics, 29(4): 505-512.

Mohamad, S., T. Hassan and M.K.I. Bader, 2008. Efficiency of conventional versus Islamic Banks: international evidence using the Stochastic 
Frontier Approach (SFA). Journal of Islamic Economics, Banking and Finance, 4(2): 107-130.

Molyneux, P. and J. Thornton, 1992. Determinants of European bank profitability: A note. Journal of Banking \& Finance, 16(6): 1173-1178.

Nienhaus, V., 1983. Profitability of Islamic PLS banks competing with interest banks: problems and prospects. Journal of Research in Islamic Economics, 1(1): 31-39.

Rahajeng, Dian Kartika, 2012. The effectiveness of shari'ah supervisory board roles in Islamic Banks.. Available at SSRN: http://ssrn.com/abstract=235783 or http://dx.doi.org /10.2139/ssrn. 2357831

Rahman, A.A., N.A. Lode and O. Othman, 2012. The Extent of Compliance with FRS 101 Standard among Malaysian Listed Companies, International Conference on Management, Economics and Finance.Kuching, Sarawak Malaysia.

Rosly, S.A., 2011. Risk-Based Pricing in Al Bai Bithaman Ajil (BBA)/Murabahah Sales: fiscal
Liability with Business and Credit risk exposure. In 14th International Business Research Conference, Crown Plaza Hotel, Sheikh Zayed Road, Dubai. UAE.

Rosly, S.S., 2010. Shari'ah parameters reconsidered. International Journal of Islamic and Middle Eastern Finance and Management, 3: 132146.

Said, R.M. and M.H. Tumin, 2011. Performance and Financial Ratios of Commercial Banks in Malaysia and China.International Review of Business Research Papers, 7(2): 157-169.

Usmani, T., 2004. An Introduction to Islamic Finance, Arham Shams

Zaman, M., 2001.Turnbull-generating undue expectations of the corporate governance, role of audit committee.Managerial Auditing Journal, 16: 59. 